\title{
Material Flow Cost Accounting in Czech Environment ${ }^{\#}$
}

\author{
Dana Kovanicová*
}

Global economy, along with climate changes and environmental legislation, attracts attention more than ever. Management of economic and environmental matters is under pressure to increase performance without negative impact on sustainability. The increasing importance of environmental problems, material and energy availability (and their increasing prices), as well as growing difficulties with managing these issues lead to composing of sets of new supportive instruments. One of such tools is the "Material flow cost accounting" (hereafter referred as "MFCA"), presented as a new method of environmental management.

\section{Nature, origin and standardization of MFCA}

The MFCA is a new method of cost recording and cost calculation that aims to reduce both costs and environmental effects at the same time (especially by means of waste reduction) and thus improves business productivity and strengths of organization's competitiveness.

In the flow of materials from raw materials to the finished product, the method calculates the amount of useless waste by-products of each manufacturing stage of process. With the aid of a material process flow chart, the method identifies processes causing losses and leads to the improvements.

\footnotetext{
\# This paper was prepared in the framework of research plan Development of Accounting and Financial Theory and its Application in Practice from Interdisciplinary Point of View (registered number MSM 6138439903).

Prof. Ing. Dana Kovanicová, CSc. - professor; Department of Financial Accounting and Auditing, Faculty of Finance and Accounting, University of Economics, Prague, W. Churchill Sq. 4, 13067 Prague 3, Czech Republic, <dkovanic@ tiscali.cz>.
} 


\subsection{Nature of MFCA}

Precise characteristics of MFCA concept are expressed in METI (2007). According to this source, the recording and calculating system under MFCA is based on following features:

a) The quantitative centers are created.

b) Each product is classified from two points of view - as a positive product (which is required) and as a negative by-product (waste or recyclable product).

c) Costs are recorded not only with respect to positive product (as the positive product costs), but also to negative product (as the negative product costs). Positive product is released to the next phase of the process in positive product cost value.

d) Costs are calculated throughout all manufacturing until the product is finished. It means that positive product costs of a partial process are added to the new input costs accruing in the following partial process and thus costs of the final product are cumulated gradually.

e) All (manufacturing or services) costs are attached to following categories:

- Material costs (costs of the main materials put in from the initial process plus various sub-materials put in by the initial process as well as by the midstream processes, and ancillary materials such as detergents, catalysts and so on).

- Energy costs (fuel, electricity, utilities and other costs influencing energy consumption). ${ }^{1}$

- System costs: direct processing costs (for example wages of laborers) as well as indirect, overhead costs (depreciation, transport, repairs, external services and so on).

- Waste treatment costs.

Hallmark of MFCA is therefore the monitoring (registration, accounting) of material/energy flows (flows of materials throughout the manufacturing process in both physical and money expression) and sorting out the outputs in each process stage to positive product(s) and waste; monitoring of processes proceeds in cost accounting. These basic

\footnotetext{
1 This item has been separated by Japan subsequently.
} 
characteristics predetermined the name of method: Material Flow Cost Accounting - MFCA.

\subsection{Origin and standardization of MFCA}

The model of MFCA was developed at the Institute of Management and Environment ${ }^{2}$ in Augsburg, Germany. Despite the original model of MFCA was created in west Europe, its applications (connected with further development) has expanded especially in Japan. ${ }^{3}$ In 1999, the Japanese Ministry of Economy, International Trade and Industry (METI) commissioned the Japan Environmental Management Association for Industry to investigate this methodology and to prepare "environmental accounting manager project" (EMAP). The Working Group published a handbook (METI, 2007) with the objective to assist in the implementation of this method. The instructions describe the concept and the basic steps that have to be taken before the MFCA application. The Japanese approach represents a deeper elaboration of the method, in particular by separating the cost of energy, which original German model includes in the material cost. It is important from the point of impact on the environment: the quality of life of future generations depends on the rational energy management significantly.

In the view of the dissemination of MFCA method as the instrument of environmental management that is able to affect the quality of the world positively, the international standardization (ISO) is now prepared. Proposal of ISO 14051 - Environmental Management-Material flow cost accounting - General framework was prepared during 2009 (METI, 2009); the draft to public discussion was edited at May, 2010 (ISO/DIS 14051, 2010). Final form should be finished at the end of 2011 or later. The objective of the standard is to define a conceptual scope of MFCA (definitions, objectives and principles, basic elements and an access to implementation).

In spite of the fact, that this standard presents no detail procedures, its preparers expect that it will be beneficial as an idea for potential users

Institut für Management und Umwelt.

3 This does not mean that some spreading of the MFCA method didn't run in Germany. For example, a project "Introducing environmental cost accounting system to corporate environmental management - developmental model for SMEs in selected sectors" was in progress in the years 2000-2003. 
around the world, regardless of their size and focus of their activities. The main users of the ISO 14051 would be business entities producing goods or providing services, as well as public sector institutions. Because ISO 14051 is considered as the standard for sustainable development all over the world, it will be transposed into the wider European (and hereby into Czech) family of environmental management standards (EMS) for sustainable development. As any international standard, ISO 14051 does not take in consideration the national particularity. It is therefore appropriate to review how the concept of MFCA meets the Czech circumstances.

\section{MFCA - an instrument of EMA in Czech environment}

The MFCA method is presented as a new method of cost accounting. Following attributes are especially highlighted:

- new accounting method,

- ability to connect both natural (physical) and monetary (financial) information,

- ability to team up the staffers of environmental management.

MFCA is applied as a part of management accounting (MA) in Czech Republic. The concept of management accounting coincides with AngloSaxon concept. In this concept, the management accounting is a skeleton for other components of information system, which were understood previously as the separate components of internal information system. Management accounting thus includes not only internal accounts, but also the completely calculating system (preliminary and actual costing) as well as the internal budgeting (besides the whole range of managerial decisionmaking jobs in the short and long term view). As can be seen, Czech managerial accounting is connected with the physical process closely, with its stocks and flows both in natural and monetary expression, both ex post and ex ante horizon. The environmental management accounting (EMA) is based on the same concept: it could be defined as a "green MA".

The EMA is oriented on internal business processes and decisionmaking methods and techniques, and as such, it is an interdisciplinary area, involving not only the workers equipped with traditional and modern management knowledge, but also the non-accounting (operating and technical) workers. Accounting staffers working in the area of EMA 
have a key role in the implementation of environmental aspects into a series of business management and information activities. They may include the solution of such problems as formulation of the strategy; the processes of planning and budgeting; assessment of investment projects; measurement of performance; activity based costing; product life cycle management; developing organizational schemes etc.

From EMA functions outlined is evident that this system generates and analyzes not only the financial or non-financial information including those natural once. Identically to management accounting (and depending on nature and purpose of management decisions) EMA addresses also the role in various time horizons: in relation to the past (when detects the reality) as well to the future, in terms of short and long aspects. Moreover, it addresses besides routine or repetitive tasks also the role of ad hoc events. EMA is not an ingredient separated from the traditional management accounting, something like its limpet, but vice versa its organic component, which completes the traditional MA by the environmental aspects (both material and energy flows and their cash expression in the form of environmental costs).

When defining EMA, we encounter many misleading inaccuracies and misunderstandings. Firstly, some believe that traditional management accounts generally detect only actual costs. From this comes the definition of MFCA as a (solely) accounting method. Secondly, some wonder about the idea that EMA would provide - besides information about flows expressed in money - also information on natural material/energy flows (though traditional MA links such information as a system). This inference leads to splitting EMA into (see for example Jasch, $2001^{4}$; IFAC, 2005 or Schaltegger et al., 2008):

- "physical (material) EMA" (PEMA), defined as a practical management of environmental accounting, which provides information about the material and energy flows,

- "monetary EMA" (MEMA), defined as financial management environmental accounting, providing the above mentioned information in money terms.

\footnotetext{
4 There are even claims that conventional cost accounting is identical to management accounting and that it captures only the monetary information, while EMA extends this area by "physical accounting" (!) and thus only combines both components (see especially pp. 4-10). Due to the mix of two different concepts (the "Anglo-Saxon" and "Controlling" ones) total confusion comes to one's mind.
} 
This leads to obscuring EMA substance. Where this misunderstanding comes from? It is obvious. The MFCA method has been developed in the country that didn't accept the Anglo-Saxon concept of internal management system, called "management accounting". Germany has implemented a system based on so-called "controlling concept", where internal accounting is oriented on ex post information expressed in money: accounts record past activities in financial expression whilst natural, physical information is observed separately, outside accounting. Therefore, the interconnection of both physical and monetary information is presented as something completely new in German concept of MFCA, while this connection is to the Czech concept of EMA inherent.

\section{MFCA versus traditional costing methods}

MFCA belongs to a wider family of methods; their task is to register the costs in order to build up the actual calculation of products. The registration (bookkeeping) in internal accounts to calculate the actual costs of performance products (as semi-finished products, work in progress, services), are known (in Czech) as cost recording and calculating methods or (in Anglo-Saxon area) as costing. Cost recording in relation to the products (by the way of internal cost centers) is historically the oldest way of organizing the cost accounts. Since the new method extends the group of cost accounting methods, it will be appropriate to identify the basic, common attributes of these methods. It makes then easier to determine different features of the new method.

\subsection{The general characteristics of traditional cost accounting methods oriented on actual costing}

Tracking the flow of materials in cost accounting both in material and in monetary description and monitoring the other costs (prime and overheads) to build up the final calculation of products is not foreign to Czech Republic. This is one of two basic ways to control the amount of the costs directly within the system of internal accounts. In this case, the internal accounting is organized with the aim to provide information about the actual costs of individual product. Because existing organizational structure doesn't generally suit such objectives, it is usually necessary to create an additional structure, targeted on the place (centers) of cost rise. These centers are often called the "cost-calculating centers" (in MFCA: "quantitative centers"). 
Implementation of traditional costing methods has a long tradition in the Czech Republic. It is sufficient to look into the last century and put in mind the post-war history of accounting development in our country.

Very elaborated applications of these methods can be encountered in a relatively short time of the central regulation of accounts, which took place from 1946 to 1990. A rich practical experience therefore exists from past to present, supported by respectable Czech theoretical research, that pursued in academic area. Its outcomes were published continually as the monographs and schoolbooks. For illustration, see Schroll et al. (1968, 1993), Hrdinová et al. (1985), Schroll, Janout, Král, Králíček (1993), Král et al. (1997, 2006), Fibírová et al. (2007). It will be useful to remember (at least as outlined) the basic types of costing methods (now known as the "traditional"), which were precisely formulated by Czech research and widely applied in practice.

\subsection{Brief overview of the traditional types of costing methods}

Basic types of traditional costing methods are derived from the conditions, under which a specific production process is in motion. Besides two extreme cases, which relate partly to simple product (one type of output is produced typically in one technologically closed unit) and partly to complex manufacture (when elaborated product passes through more technologically separate units), further characteristics are considered. The most important ones are: nature (type) of the manufacturing process; nature (type) of the product; organization of batching; the existence of a work in progress and (in specific cases) the jointing production.

The combination of manufacturing conditions in a particular company suggests the organization of the internal accounts with the aim to track the actual costs in relation to product and to draw up the actual (final) costing. Notwithstanding the joint production, which by their nature is out of the considered series, four basic costing methods have been developed to aid the practice: the simple method, the phase method, the step-by step method and the job-order method. It should be noted that these methods satisfy the absorption method of calculation, whose essence is to quantify the average amount of prime costs and overheads per unit of output. ${ }^{5}$

5 In addition, there are other methods of calculation. For example, the "Direct Costing" method that assigns to the product only the variable costs, while the fixed costs are 
The necessity to compare the actual level of costs and their standard (norm) level continuously with the aim to detect the usage variations led to supplementing and improving these basic methods. Two methods emerged independently hereby. The norm method of the cost register and calculation was evolved in the Eastern countries, while the method of standard costing was developed in Western countries. It should not miss attention, that the consumption of materials is recorded both monetary and physically in all methods.

\section{3 MFCA versus traditional methods of costing}

The identical features were mentioned primarily. In MFCA as well as in all basic costing methods analyzed previously, it is necessary to create costing centers (in MFCA called - somewhat inappropriately - as "quantitative" centers), which are able to fulfill requirements of actual costing. Each center monitors actual costs that incurred in it. Actual consumption of any prime material (possibly energy) is recorded on one place both financially and physically. Hereby the common features end.

Unlike traditional methods, MFCA method is not elaborated in detail with regard to specific production conditions (which is still its greatest disadvantage). The traditional methods calculate during the process too, but excluding step-by-step method the decisive factor is the calculation of final product exiting from the last manufacturing stage (the last center), while MFCA emphasis the calculation of the "final" (positive) product of each center representing intermediary stage of the process. In the traditional calculation, any waste is included into the final product as a part of its costs, while in MFCA any waste is calculated separately as a negative product and doesn't enter into the next stage of processing. Traditional methods classify costs on prime and overheads, while MFCA categorizes costs on material/energy and systemic costs (which in nature are the processing cost).

\section{MFCA adoption with regard to national specificity}

Relatively long tradition in implementation of costing methods in our country requires adopting of MFCA method to our environmental laws with some caution. Its taking over would not ignore or even discourage

tracked as the cost of the period. Another example: method of Activity Based Costing $(\mathrm{ABC})$, which is based on assigning costs to activities of the production processes. 
existing costing applications; MFCA method ought to draw from the rich repository of our experience, in particular in relation to practical elaborations of traditional methods. Adoption of MFCA in Czech environment should be based on the following premises:

- MFCA is not completely a new method of calculation; it should be understood as a modification of the existing methods of costing.

- MFCA is not a matter of (cost) accounting only, but it is the efficient instrument of all internal control system oriented to sustainability development - an instrument of the environmental management (this opinion is endorsed e.g. in Hyršlová et al., 2008).

- MFCA should be taken into entities' information system with regard to its existing development in the area of cost management and with consideration of the extent of applied integration, rather as a foreign element.

- Classification of environmental management accounting on "physical" one (PEMA) and "monetary" one (MEMA) is to contemporary Czech concept (based on Anglo-Saxon approach) strange.

- It is necessary to achieve the conformity of MFCA terminology with existing terminology used in Czech professional literature and economic praxes. This especially relates to such wording as "system costs" or "quantitative centers".

- To make precise both the contents of system (or process) costs and the methodology related to the assigning of process costs partly to centers and partly to both (positive and negative) types of products.

\section{Conclusion}

The entity, which feels responsibility for the sustainability, doesn't necessarily implement the environmental dimension into its overall management and information system. It can apply minor procedures aimed to the partial improvement respecting the sustainability. One of such procedures is the MFCA method, which extends and upgrades the family of traditional costing methods.

In cases when the top management of a firm doesn't respects the sustainability, the "bottom-up" introduction of this method causes as the 
environmental injection, which infects other non-accounting departments. It draws them gradually in efforts for sustainable development through natural internal relations between them, without omitting the cost effectiveness and competitiveness. This is the great strength of the MFCA method.

\section{References}

[1] Fibírová, J. - Šoljaková, L. - Wagner, J. (2007): Nákladové a manažerské účetnictví. Praha, ASPI, 2007.

[2] Hrdinová, D. - Schroll, R. - Misterková, J. (1985): Př́íklady a úlohy ke kursu kontrola nákladů a kalkulace. Praha, SPN, 1985.

[3] Hyršlová, J. - Bednař́ková, M. - Hájek, M. (2008): Material Flow Cost Accounting: "Only" a Tool of Environmental Management or a Tool for the Optimalisation of Corporate Production Process? Scientific papers of the University of Pardubice. Series A. Faculty of Chemical Technology, 2008, vol. 14, pp. 131-145.

[4] ISO/DIS 14051 (2010): Environmental Management - Material Flow Cost Accounting - General Framework. Draft. [on-line], Wien, Austrian Standards Institute, c2010, [cit. 31. 1. 2011], $<$ https://www.astandis.at/shopV5/Preview.action;jsessionid=7BF600 E0E4596C2347A74F31C6EA51D9?preview=\&dokkey=365758\&sel ectedLocale>.

[5] Jasch, C. (2001): Environmental Management Accounting. Procedures and principles. New York, United Nations, 2001.

[6] IFAC (2005): Environmental Management Accounting. International Guidance Document. New York, International Federation of Accountants Committee, 2005.

[7] Král, B. et al. (1997): Nákladové a manažerské účetnictví. 1. vydání, Praha, Prospektrum, 1997.

[8] Král, B. et al. (2006): Manažerské účetnictví. 2. rozšîř́ené vydání. Praha, Management Press, 2006. 
[9] METI (2007): Guide for Material Flow Cost Accounting (Ver. 1). [on-line], Tokyo, Environmental Industries Office, Ministry of Economy, Trade and Industry, c2007, [cit.: 25. 2. 2010], $<$ http://www.meti.go.jp/policy/eco_business/pdf/mfca\%20guide2007 0822.pdf>.

[10] METI (2009): Materialflow cost accounting with ISO 14051. [on-line], Tokyo, ISO Management Systems, January-February 2009, c2009, [cit.: 5. 1. 2010], $<$ http://www.sis.se/PDF/iso_14051_mfca_ims_1-2-2009_e.pdf>.

[11] Schaltegger, S. - Bennett, M. - Burritt, R. - Jasch, C. (2008): Environmental Accounting for Cleaner Production. Eco-efficiency in Industry \& Science. New York/Heidelberg, Springer, 2008.

[12] Schroll, R. et al. (1968): Účetnictví v průmyslu. (Vnitropodnikové účetnictví a kalkulace). Praha, SNTL/ALFA, 1968.

[13] Schroll, R. - Janout, J. - Král, B. - Králíček, V. (1993): Manažerské účetnictví v podnicích tržního hospodářství. VŠE v Praze, Fakulta financí a účetnictví, 1993. 


\title{
Material Flow Cost Accounting in Czech Environment
}

\author{
Dana KOVANICOVÁ
}

\begin{abstract}
The theme of article is the draft of ISO 14051-Environmental Management - Material flow cost accounting - General framework, whose final form should be finished at the end of 2011 or later. This standard does not take in consideration the national particularity. Therefore, the main aim of this paper is to review how the concept of MFCA meets the Czech conditions.

The MFCA (as one of cost accounting methods) is in Czech Republic a part of management accounting (MA), which coincides with the AngloSaxon concept. MA is a skeleton for other components of information system, closely connected with the physical process. The environmental management accounting (EMA) is based on the same concept: it could be defined as a "green MA". When defining EMA, we encounter many misleading inaccuracies and misunderstandings. Firstly, some believe that traditional management accounts generally detect only actual costs. From this, MFCA is defined as a (solely) accounting method. Secondly, EMA is segmented to physical part (PEMA) and monetary part (MEMA). This leads to obscure the substance of EMA.

Implementation of costing methods has a long tradition in Czech Republic. Basic types of traditional costing methods (unlike MFCA) have been derived from the conditions, under which specific production process continues. MFCA adoption in our conditions should be comprehended as an upgrading and enhancement of the traditional methods, not as their suppression.
\end{abstract}

Key words: Material Flow Cost Accounting; Costing; Management Accounting; Environmental Management Accounting.

JEL classification: Q56; M41. 